\title{
Türkiye'de Postmortem İzole Edilen HIV-1 Suşlarında Moleküler Epidemiyoloji
}

\section{Postmortem Molecular Epidemiology of HIV-1 Strains Isolated in Turkey}

\author{
Nihan ZIYADE ${ }^{1}$, Murat SAYAN ${ }^{2}$, Neval ELGÖRMÜş ${ }^{1}$, Yalçın BÜYÜK ${ }^{3}$ \\ 1 istanbul Adli Tıp Kurumu, Postmortem Mikrobiyoloji Laboratuvarı, İstanbul. \\ ${ }^{1}$ Council of Forensic Medicine, Postmortem Microbiology Laboratory, Istanbul, Turkey. \\ ${ }^{2}$ Kocaeli Üniversitesi Tıp Fakültesi, PCR Ünitesi, Kocaeli. \\ 2 Kocaeli University Faculty of Medicine, PCR Unit, Kocaeli, Turkey. \\ 3 istanbul Adli Tıp Kurumu, Morg ihtisas Dairesi, İstanbul. \\ ${ }^{3}$ Council of Forensic Medicine, Department of Morque, Istanbul, Turkey.
}

Makale Atıfi: Ziyade N, Sayan M, Elgörmüş N, Büyük Y. Türkiye'de postmortem izole edilen HIV-1 suşlarında moleküler epidemiyoloji. Mikrobiyol Bul 2019;53(4):374-387.

\section{ÖZ}

İnsan immün yetmezlik virüsü (HIV), morfolojik ve biyolojik olarak birbirine benzeyen, ancak zarf glikoproteinleri ve diğer antijenik epitoplarda farklılık gösteren HIV-1 (grup M, N, O ve P) ve HIV-2 (grup A-H) olmak üzere iki genotip içermektedir. Dünya çapındaki enfeksiyonların $\% 95$ 'inden sorumlu tutulan HIV-1 M grubu dokuz alt tipe ayrılmaktadır. Alt tiplerin yanında, HIV-1 grup M'nin altında "dolaşan rekombinant formlar (CRF)" ve "özgün rekombinant formlar (URF)" olmak üzere iki rekombinant form tipi yer almaktadır. Türkiye'de ilk HIV/kazanılmış immün yetmezlik sendromu (AIDS) olgusu 1985 yllında bildirilmiş, olgu sayısı günümüzde, Sağlık Bakanlığının Ekim 1985-Kasım 2018 HIV/AIDS sürveyans verilerine göre 1736 'sı AIDS'li olmak üzere toplam 18.557'ye ulaşmıştır. Bu çalışmada; otopsi olgularından HIV polimeraz zincir reaksiyonu (PCR) ile saptanan HIV pozitif olgulardan izole edilen HIV-1 suşlarının alt tiplendirmesi, prevalansının belirlenmesi ve ilaç direncinin saptanması amaçlanmıştır. Çalışmaya; 2011-2017 yılları arasında otopsi yapılması için gelen, Postmortem Mikrobiyoloji Laboratuvarında serolojik tarama ve HIV PCR çalışılması amacıyla gönderilen olgulardan HIV pozitif saptanan 28 olgu [17 erkek, 11 kadın; yaş aralığı: 3 ay-66 yıl (median: 35 yıl)] alınmıştır. HIV-1 izolatlarının alt tiplendirmesinde en yaygın kullanılan algoritma [HIVdb Stanford Üniversitesi genotipik direnç değerlendirme algoritması] (www.hivdb.stanford.edu) kullanılmıştır. Filogenetik ağaç HIV-1 ters transkriptaz ( $p o l)$ bölgesinin direkt dizilemesine göre yapılmış olup, filogenetik analiz 23 olgu üzerinden değerlendirilmiştir. Los Alamos Ulusal Laboratuvarı HIV sekans veritabanında (LANL, https://www.hiv.lanl.gov) yer alan konsensus suşların tüm genomlarından 870 baz çiftlik bölümü kesilerek kullanılmış; filogenetik analiz CLC Sequence Viewer v8.0 (Qiagen Aarhus A/S, www. qiagenbioinformatics.com) programı ile yapılmışıı. Filogenetik ağaç neighbor-joining yöntemine ve JukesCantor nükleotit uzaklık ölçeğine göre oluşturulmuş ve bootstrap değeri 1000 olarak alınmıştır. Çalışmamızda alt tip B $(\% 39.3 ; 11 / 28)$ en sık karşılaşılan tip olmuştur. Alt tip A (\%17.9; 5/28), CRF02_AG (\%14.3; 4/28), alt tip C (\%10.7; 3/28), B+CRF02_AG rekombinantı (\%3.6; 1/28), CRF01_AE (\%3.6; 1/28), alt tip D $(\% 3.6 ; 1 / 28)$, ayrıca alt tip $F(\% 3.6 ; 1 / 28)$ ve alt tip $G(\% 3.6 ; 1 / 28)$ suşlarının da dolaşımda olduğu 
görülmektedir. Yapılan analizlerde örneklerin \%32.1'inde (9/28) mutasyon saptanmıştır. Bunlar; nükleozid revers transkriptaz inhibitörü (NRTI) direncinden sorumlu M41L, T215C, K65R, M184V; nonnükleozit revers transkriptaz inhibitörü (NNRTI) direncinden sorumlu K103N, Y181C, G190A ve proteaz inhibitörü (PI) direncinden sorumlu D30N, M46I olarak izlenmiştir. Örneklerin \%21.4'ünde (6/28) NRTI, \%7.1'inde (2/28) NNRTI ve \%3.6'sında (1/28) PI mutasyonu bulunmuştur. Çalışmamızda analiz edilen örnek sayısı az olmakla birlikte, Türkiye'de dolaşan suşlarla benzeştiğini söyleyebiliriz. Çalışmamızın sonuçları; ülkemizde $B$ alt tipinin hala baskın olmasına rağmen, B olmayan alt tiplerin de bulunduğunu ve son yıllarda CRF oranında artış olduğunu bildiren diğer çalışmaları da desteklemektedir. Filogenetik analiz HIV-1 alt tiplerinin belirlenmesinde altın standart olarak kabul edilmektedir. HIV ile ilgili moleküler epidemiyolojik calışmalar, o ülke içinde HIV alt tip paternlerinin ve yayılma yollarının izlenmesinde önemli olabilmektedir. Sonuç olarak; postmortem HIV sekanslarının bir veri tabanında toplanması fırsatı oluşmuş görünmektedir ve bu veri tabanı genişledikçe adli açıdan kullanılabilirliği ortaya çıkabilir. Bu nedenle de HIV alt tip ve mutasyon bilgilerinin kullanışlı olabileceği düşünülmektedir.

Anahtar kelimeler: HIV-1; alt tip; filogenetik analiz; moleküler epidemiyoloji; postmortem mikrobiyoloji.

\section{ABSTRACT}

Human immunodeficiency virus (HIV) comprises two genotypes, namely HIV-1 (group M, N, O and P) and HIV-2 (group A to $\mathrm{H}$ ), which differ in their envelope glycoproteins and other antigenic epitopes despite their morphological and biological resemblance.Group M of HIV-1 responsible for $95 \%$ of HIV infections worldwide is composed of nine subgroups. In addition to subgroups, group $\mathrm{M}$ contains also two recombinant forms, known as circulating recombinant form (CRF) and unique recombinant form (URF). The first case of HIV/acquired immun deficiency virus (AIDS) in Turkey was reported in 1985 and the current number of cases reached a total of 18.557 including 1736 with AIDS based upon the surveillance data of Ministry of Health between October 1985 and November 2018. The aim of this study was to determine the prevalence of HIV-1 strains isolated from HIV positive autopsy cases detected by HIV polymerase chain reaction (PCR) and determine drug resistance. Twenty eight cases [17 males, 11 female: age ranged between 3 months and 66 years (median: 35 years)] found to be HIV positive among the autopsy cases sent for HIV1 PCR study and serological screening between 2011-2017 were recruited in the study. For identification of subtypes in HIV-1 isolates, most-preferred analysis tool was used [HIVdb Stanford University Genotypic Resistance Interpretation Algorithm (www.hivdb.stanford.edu)]. Phylogenetic tree was made according to direct sequencing of HIV-1 reverse transcriptase ( $p o /)$ region and phylogenetic analysis was evaluated in 23 cases. Los Alamos National Laboratory were trimmed from full-length genomes. Phylogenetic analysis of the 870 base pair of the pol gene region was performed using CLC Sequence Viewer v8.0 (Qiagen Aarhus $\mathrm{A} / \mathrm{S}$, www.qiagenbioinformatics.com) software. The phylogenetic tree was obtained according to the neighbor-joining method and the Jukes-Cantor nucleotide distance scale and bootstrap value was set at 1000 . In our study, subtype B was found to be most frequent type $(39.3 \% ; 11 / 28)$. Subtype A $(17.9 \% ; 5 / 28)$, CRF02_AG (14.3\%; 4/28), subtype C (10.7\%; 3/28), B+CRF02_AG recombinant (3.6\%; 1/28), CRF01_AE $(3.6 \% ; 1 / 28)$, subtype $D(3.6 \% ; 1 / 28)$, as well as subtype $F(3.6 \% ; 1 / 28)$ and subtype $G(3.6 \% ; 1 / 28)$ strains were also detected in the circulation. Analysis of our results showed that $32.1 \%(9 / 28)$ of the samples exhibited resistance mutations. Detected mutations were as follows: M41L, T215C, K65R, M184V, responsible for nucleoside reverse transcriptase inhibitor (NRTI) resistance; K103N, Y181C, G190A, responsible for non-nucleoside reverse transcriptase inhibitor (NNRTI) resistance; D30N, M46I, responsible for protease inhibitor (PI) resistance. NRTI, NNRTI and PI mutation rates in the samples were found as $21.4 \%, 7.1 \%$ and $3.6 \%$, respectively. Although number of samples analyzed in our study is low, we can propose that they resemble the strains circulating in Turkey. The results of our study; although the subtype B is still dominant in our country, it supports other studies reporting that there are non-B subtypes and an increase in CRF rates in recent years. Phylogenetic analysis is widely regarded as the gold standard technique to determine the subtypes of HIV-1. Molecular epidemiologic studies related to HIV may be important in monitoring HIV subtype patterns and spreading pathways in that country. As a result; the opportunity to collect postmortem HIV sequences in a database appears to have occurred, and as this database expands, its usability is available. Therefore, it is thought that HIV subtypes and mutation information may be useful.

Keywords: HIV-1; subtype; phylogenetic analysis; molecular epidemiology; postmortem microbiology. 


\section{Giriş}

İnsan immün yetmezlik virüsü (HIV) hızlı mutasyon ve rekombinasyon eğilimi nedeniyle yüksek genetik değişkenlik özelliği olan bir RNA virüsüdür. HIV'ın günümüzde HIV1 (grup $1 \mathrm{M}, \mathrm{N}, \mathrm{O}$ ve $\mathrm{P}$ ) ve HIV-2 (grup A-H) olmak üzere iki genotipi tanımlanmıştır ${ }^{1}$. Dünya çapındaki enfeksiyonların \%95'inden sorumlu tutulan HIV-1 M grubu, A-D, F-H ve J-K olmak üzere dokuz alt tipe ayrılmaktadır ${ }^{2}$. Alt tipler arasındaki rekombinasyon sonucunda dolaşan rekombinant formlar [circulating recombinant form (CRF)] ve özgün rekombinant formlar [unique recombinant form (URF)] oluşur. Rekombinant formlar epidemiyolojik olarak birbirleriyle ilişkisi olmayan üç ya da daha fazla kişide saptanırsa CRF, diğerleri URF olarak isimlendirilir². Rekombinantların şu anda dünya çapında HIV-1 enfeksiyonlarının en az \%20'sinden sorumlu olduğu tahmin edilmektedir. Sahra altı Afrika'da en yaygın alt tip ' $A$ ' iken, Kuzey Amerika, Avustralya, Avrupa ve ülkemizde ise alt tip ' $B$ ' daha sık saptanmaktadır ${ }^{3}$. HIV'ın genetik değişkenliği tanıda, patogenezde, viral yük ölçümünde, ilaç direncinde, antiretroviral tedaviye (ART) yanıtın izlenmesinde, hastalığın ilerlemesinde ve aşı çalışmalarında önemli rol oynamaktadır ${ }^{2,4}$.

Tedavide kullanımları kolay ve yan etkileri daha az olan kombinasyon ilaçlar ile HIV enfeksiyonu ölümcül bir hastalık olmaktan çıkıp, yaşam boyu ilaç kullanımını gerektiren bir tür kronik hastalığa dönüşsmüştür. Ancak, HIV'a yönelik antiretroviral ilaçlara rağmen virüsün insan vücudundan tamamen yok edilmesi henüz mümkün değildir 5 .

Dünya genelinde "The Joint United Nations Programme on HIV/AIDS (UNAIDS)" verilerine göre; 2016 yılı itibariyle 36.7 milyon HIV ile enfekte, 1.8 milyon ise yeni olgu bulunmaktadır 6 . Ülkemizde ise T.C. Sağlık Bakanlığı verilerine göre; ilk olgunun görüldüğü 1985 yılından 01 Kasım 2018 tarihine kadar doğrulama testi pozitif tespit edilerek bildirimi yapılan 18.557 HIV pozitif kişi ve 1736 kazanılmış immün yetmezlik sendromu (AIDS) olgusu bildirilmiştir ${ }^{7}$. Coğrafi açıdan Türkiye HIV/AIDS olgularının artış gösterdiği Doğu Avrupa ve Orta Asya bölgeleri arasında yer almaktadır ${ }^{8}$. Bu çalışmada; otopsi olgularından HIV polimeraz zincir reaksiyonu (PCR) ile saptanan HIV pozitif olgulardan izole edilen HIV-1 izolatlarının filogenetik bir yaklaşımla alt tiplendirmesi, prevalansının belirlenmesi ve ilaç direncinin saptanması amaçlanmıştır.

\section{GEREÇ ve YÖNTEM}

Bu araştırma, Adalet Bakanlığı Adli Tıp Kurumunun Eğitim ve Bilimsel Araştırma Komisyonunun onayı ile gerçekleştirildi (Sayı: 21589509/986 ).

\section{Çalışma Grubu}

Çalışmaya 2011-2017 yılları arasında, otopsi yapılması amacıyla gelen, Postmortem Mikrobiyoloji Laboratuvarına serolojik tarama ve HIV PCR çalışılması amacıyla gönderilen olgulardan HIV pozitif saptanan 28 olgu [17 erkek, 11 kadın; yaş aralığı: 3 ay-66 yıl (median: 35 yıl)] dahil edildi. 


\section{HIV-1 RNA Saptanması}

Otopsi olgularından serolojik ve PCR incelemeleri için özellikle büyük damarlardan (femoral arter, femoral ven, juguler ven gibi) kan alındı. Kanlar EDTA'lı tüplere konulup, mümkün olan en hızlı şekilde laboratuvara gönderildi. Postmortem kan örnekleri $10.000 \mathrm{rpm}$ 'de 10 dakika santrifüj edildikten sonra, elde edilen plazma numuneleri alikotlandı ve çalışııncaya kadar $-80^{\circ} \mathrm{C}^{\prime}$ de saklandı. Plazma örneklerinden Qiasymphony (Qiagen, Almanya) otomatik izolasyon cihazında RNA izolasyonu yapıldı. İzole edilen örneklerden, Rotor Gene Q (Qiagen, Almanya) cihazında Artus HIV-1 QS-RGQ (Qiagen, Almanya) kiti ile gerçek zamanlı PCR (Rt-PCR) yöntemiyle kalitatif olarak HIV RNA düzeyleri çalışıldı.

\section{HIV-1 pol Geninin Dizilenmesi ve Alt Tiplendirme}

HIV-1 pol geninin (ters transkriptaz domaini, kodon 41-232) dizilenmesinde, "The French National Agency for AIDS Research (ANRS)" AC11 Direnç Grubunun $P C R$ ve dizileme algoritmasından yararlanıldı (www.hivfrenchresistance.org). Kullanılan dış primerler MJ3: 5'-AGT AGG ACC TAC ACC TGT CA-3' ve MJ4: 5'-CTG TTA GTG CTT TGG TTC CTC T-3'; iç primerler (573 bp) A(35): 5'-TTG GTT GCA CTT TAA ATT TTC CCA TTA GTC CTA TT-3' ve NE1(35): 5'-CCT ACT AAC TTC TGT ATG TCA TTG ACA GTC CAG CT-3'; sekanslama primeri ise A(20): 5'-ATT TTC CCA TTA GTC CTA TT-3' şeklinde belirlendi. HIV-1 cDNA sentezi M-MuLV ters transkriptaz enziminin kullanıldığı "first strand cDNA synthesis (Thermo Scientific Inc, Fermentas, Litvanya)" kiti ile gerçekleştirildi. PCR ürünleri, "DNA engine peltier (BioRad Laboratories, $A B D)^{\prime \prime}$ ISı döngü platformunda, $95^{\circ} \mathrm{C}^{\prime}$ de 10 dakika ön denatürasyon, 45 döngü $95^{\circ} \mathrm{C}^{\prime}$ de 45 saniye denatürasyon, $55^{\circ} \mathrm{C}^{\prime}$ de 45 saniye primer bağlanma ve $72^{\circ} \mathrm{C}^{\prime}$ de 45 saniye uzama koşullarında elde edildi. Primerler, PCR için $0.2 \mu \mathrm{M}$, dizi için $0.3 \mu \mathrm{M}$ son konsantrasyonunda kullanıldı. Tüm PCR ürünleri "high pure PCR product purification (Roche Diagnostics, Almanya)" kiti ile saflaştırıldı ve ürünler ABI PRISM 310 platformunda "DYEnamic ET terminator cycle sequencing (Amersham Pharmacia Biotech Inc, $A B D)^{\prime \prime}$ kiti kullanılarak dizilendi. Direkt dizileme için kullanılan PCR protokolü; 35 döngü $95^{\circ} \mathrm{C}^{\prime}$ de 20 saniye denatürasyon, $50^{\circ} \mathrm{C}^{\prime}$ de 25 saniye primer bağlanması ve son olarak $60^{\circ} \mathrm{C}^{\prime}$ de 2 dakika uzama olarak gerçekleştirildi. Elektroferogramlar "Vector NTI v5.1 (InforMax, Invitrogen, Life Science Software, ABD)" programı ile elde edildi. HIV-1 izolatlarının alt tiplendirmesinde en yaygın kullanılan algoritma [HIVdb Stanford Üniversitesi genotipik direnç değerlendirme algoritması (www.hivdb.stanford.edu)] kullanıldı ${ }^{9}$.

\section{Filogenetik Analiz}

HIV-1 alt tip dağılımı "neighbor-joining" yöntemine ve Jukes-Cantor nükleotit uzaklık ölçeğine göre filogenetik olarak analiz edildi. Ağacın yapımında HIV-1 pol geni; proteaz (1-99 aa arası) + RT (1-235 aa arası) domainleri kullanıldı ve dizi uzunluğu 870 bp olarak belirlendi. Bootstrap değeri 1000 olarak alındı. Filogenetik ağaç CLC Sequence Viewer v8.0 (Qiagen Aarhus A/S, www.qiagenbioinformatics.com) programı ile yapıldı. 


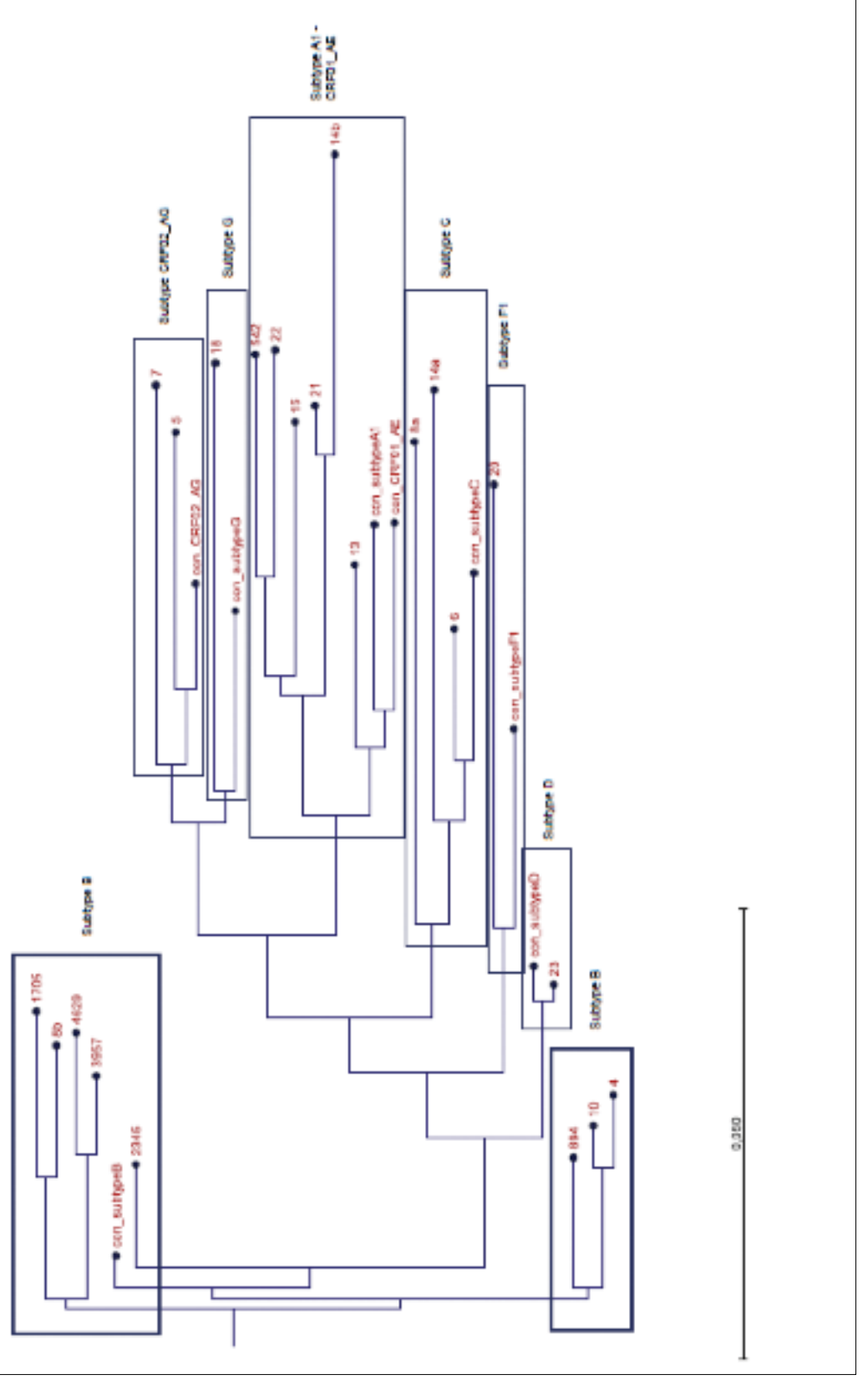

Şekil 1. Filogenetik ağaç, Neighbor Joining yöntemine ve Jukes-Cantor nükleotit uzaklık ölçeğine göre yapılmıştır. Ağacın yapımında HIV-1 pol geni; proteaz (1-99 aa arası) + RT (1-235 aa arası) domainleri kullanıldı ve sekans uzunluğu 870 bp olarak belirlenmiştir. Bootstrap değeri 1000 olarak alınmıştır. Filogenetik ağaç CLC Sequence Viewer v8.0 (Qiagen Aarhus A/S, www.qiagenbioinformatics.com) programı ile yapılmıştır. Referans suşlar, Los Alamos HIV sekans veri tabanında (LANL, https://www.hiv.lanl.gov) yer alan konsensus suşlardan seçilmiştir. 


\begin{tabular}{|lcc|}
\hline \multicolumn{2}{l|}{ Tablo I. Incelenen Örneklerin Uyruğa Göre Dă̆ıımı } & \\
\hline T.C. vatandaşı & Olgu sayısı & $\%$ \\
Afrika vatandaşı & 15 & 53.6 \\
Türkmenistan vatandaşı & 8 & 28.6 \\
Gürcistan vatandaşı & 2 & 7.1 \\
Moldova vatandaşı & 1 & 3.6 \\
Hüviyeti meçhul & 1 & 3.6 \\
Toplam & 1 & 3.6 \\
\hline
\end{tabular}

Referans suşlar, Los Alamos HIV sekans veri tabanında (LANL, https://www.hiv.lanl.gov) yer alan konsensus suşlardan seçildi (Şekil 1). Ancak 2, 7, 8, 11 ve 19 nolu suşlar, sekanslamada kısa okunduğu için (<300 bp) ağaca dahil edilmedi.

\section{BULGULAR}

Çalışmaya alınan olguların 17 (\%60.7)'si erkek, 11 (\%39.3)'i kadın olup, yaşları 3 ay66 yıl (yaş ortalaması: 36.3) arasında değişmektedir. Yirmi sekiz olgunun 15 (\%53.6)'i Türk vatandaşı olup, 12 (\%42.8)'si yabancı uyrukludur. Bir (\%3.6) olgunun da kimlik bilgilerine ulaşılamamıştır (Tablo I). Çalışma grubunun cinsiyet, yaş, HIV-1 alt tip dağılımı, klinik öykü, ko-enfeksiyon varlığı ve otopsi sonuçları Tablo II'de gösterilmiştir.

Filogenetik analiz sonuçlarına göre izole edilen suşların alt tip dağılımı; 11 (\%39.3) alt tip B, 5 (\%17.9) alt tip A, 4 (\%14.3) CRF02_AG, 3 (\%10.7) alt tip C, 1 (\%3.6) B+CRF02_AG rekombinantı, 1 (\%3.6) CRF01_AE, 1 (\%3.6) alt tip D, 1 (\%3.6) alt tip F ve 1 (\%3.6) alt tip $G$ şeklinde bulunmuştur. Buna göre olgularda saptanan baskın tipin alt tip B olduğu izlenmiştir. Türk vatandaşları ve yabancı uyruklu olguların cinsiyet ve alt tip dağılımı Tablo III'te verilmiştir.

Yapılan analizlerde örneklerin \%32.1'inde (9/28) mutasyon saptanmıştır. Bunlar; nükleozit revers transkriptaz inhibitörü (NRTI) direncinden sorumlu M41L, T215C, K65R, M184V; non-nükleozit revers transkriptaz inhibitörü (NNRTI) direncinden sorumlu K103N, Y181C, G190A ve PI proteaz inhibitörü (PI) direncinden sorumlu D30N, M46I olarak izlenmiştir. Örneklerin \%21.4'ünde (6/28) NRTI, \%7.1'inde (2/28) NNRTI ve \%3.6'sında (1/28) PI mutasyonu bulunmuştur. Örneklerde saptanan direnç mutasyonları Tablo IV'te gösterilmiştir. Saptanan bazı mutasyonlar (NRTI için; A62V ve T215N, NNRTI için; A98G, L100F, K103E, E138A ve V179E/D, PI için; L10V, K20I ve A71T) WHO TDRM listesinde bulunmadığı için klinik önemde kabul edilmemiş ve değerlendirmeye alınmamıştır. 


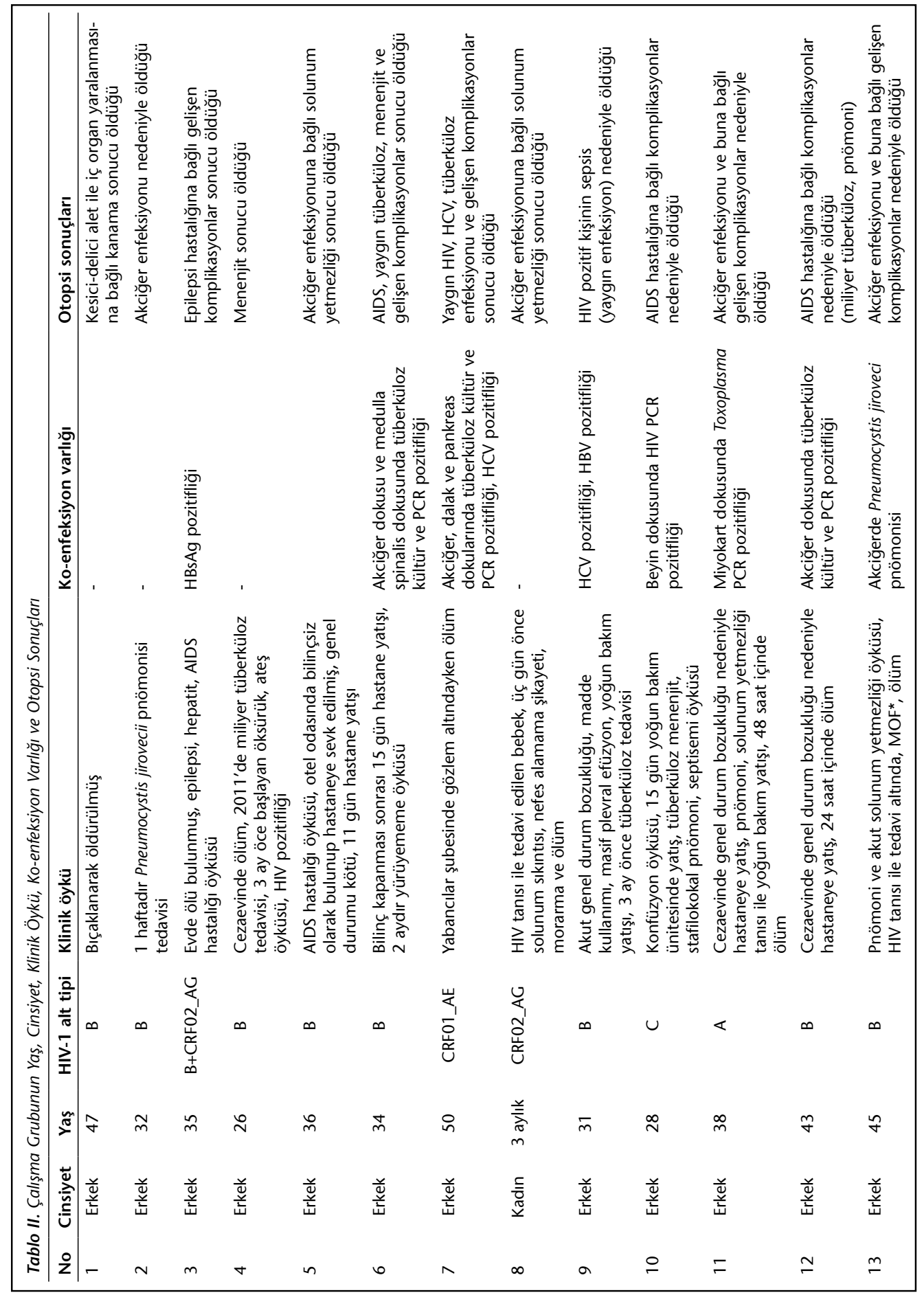




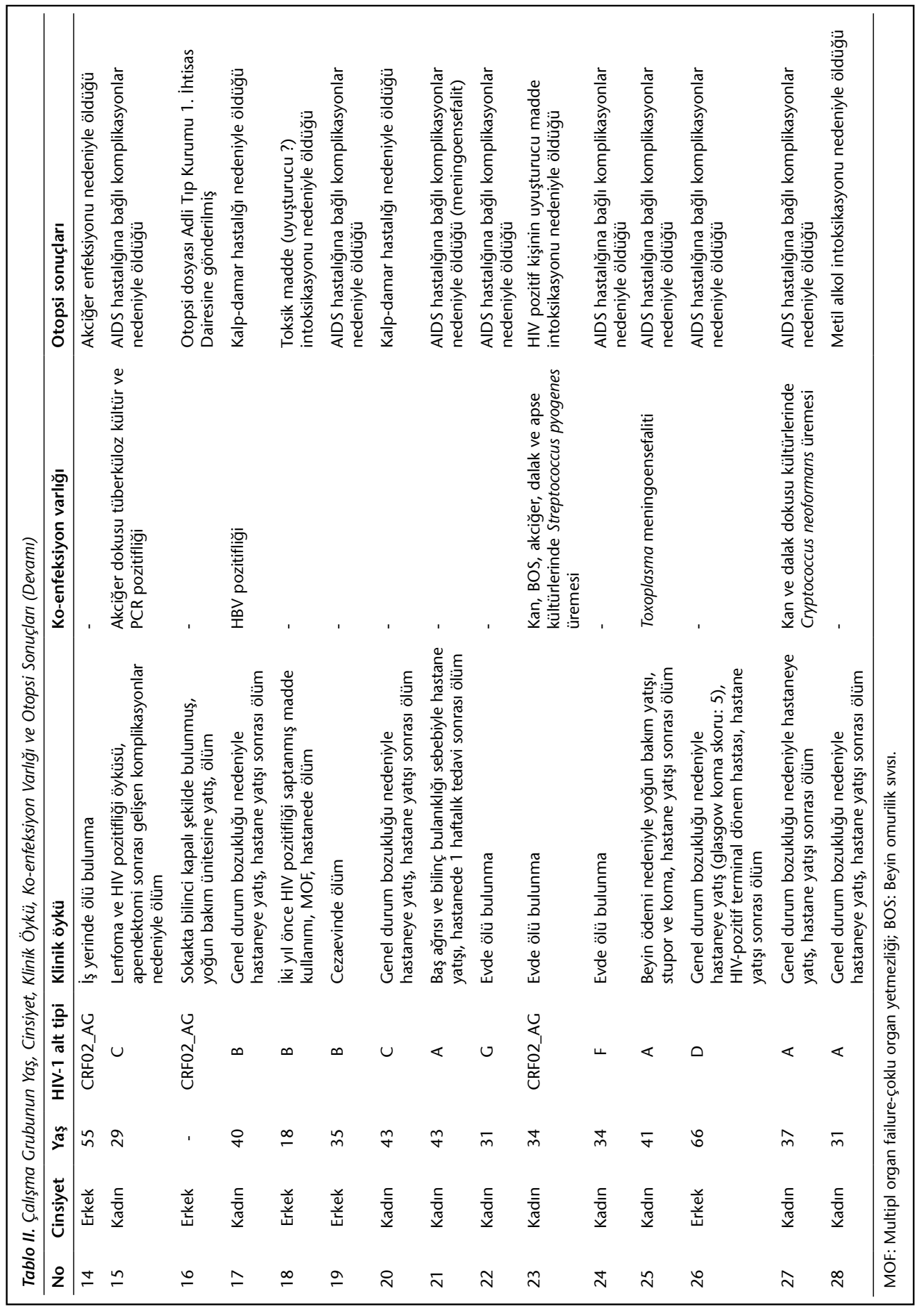




\begin{tabular}{|c|c|c|c|c|c|}
\hline \multicolumn{2}{|c|}{ T.C. Vatandaşı } & \multicolumn{2}{|c|}{ Yabancı Uyruklu } & \multicolumn{2}{|c|}{ Genel } \\
\hline Cinsiyet & n (\%) & Cinsiyet & n (\%) & Cinsiyet & n (\%) \\
\hline Erkek & $12(80)$ & Erkek & $5(38.5)$ & Erkek & $17(60.7)$ \\
\hline Kadın & $3(20)$ & Kadın & $8(61.5)$ & Kadın & $11(39.3)$ \\
\hline Toplam & $15(100)$ & Toplam & $13(100)$ & Toplam & $28(100)$ \\
\hline \multicolumn{6}{|c|}{ Olguların Alt Tip Dağılımı } \\
\hline \multicolumn{2}{|c|}{ T.C.Vatandaşı } & \multicolumn{2}{|c|}{ Yabancı Uyruklu } & \multicolumn{2}{|c|}{ Genel } \\
\hline Alt tip & n (\%) & Alt tip & n (\%) & Alt tip & n (\%) \\
\hline B & $10(66.7)$ & B & $1(7.7)$ & B & $11(39.3)$ \\
\hline CRF02_AG & $2(13.3)$ & CRF02_AG & $2(15.4)$ & CRF02_AG & $4(14.3)$ \\
\hline A & $1(6.7)$ & A & $4(30.8)$ & A & $5(17.9)$ \\
\hline $\mathrm{F}$ & $1(6.7)$ & $\mathrm{F}$ & - & $\mathrm{F}$ & $1(3.6)$ \\
\hline \multirow[t]{5}{*}{$\mathrm{B}+\mathrm{CRF} 02 \_\mathrm{AG}$} & $1(6.7)$ & C & $3(23.1)$ & C & $3(10.7)$ \\
\hline & & $\mathrm{D}$ & $1(7.7)$ & D & $1(3.6)$ \\
\hline & & G & $1(7.7)$ & G & $1(3.6)$ \\
\hline & & CRF01_AE & $1(7.7)$ & CRF01_AE & $1(3.6)$ \\
\hline & & & & $\mathrm{B}+\mathrm{CRF} 02$ AG & $1(3.6)$ \\
\hline
\end{tabular}

\begin{tabular}{lccc}
\multicolumn{4}{l}{ Tablo IV. Örneklerde Saptanan Direnç Mutasyonları } \\
\hline Antiretroviral ilaç sınıfı & Mutasyon paterni & $\mathbf{n}$ & $\%$ \\
\hline NRTI & M41L, K65R, M184V, T215C & 6 & 21.4 \\
NNRTI & K103N, Y181C, G190A & 2 & 7.1 \\
PI & D30N, M46I & 1 & 3.6 \\
Toplam & 9 & 32.1 \\
\hline NRTI: Nükleozit revers transkriptaz inhibitörleri, NNRTI: Non-nükleozit revers transkriptaz inhibitörleri, Pl: Proteaz \\
inhibitörleri.
\end{tabular}

\section{TARTIŞMA}

AIDS hastalığı 1980'li yılların başlarında ilk tanımlandıktan sonra; kadın ve erkeklerin oranı kadınlar lehine \%8-10 iken, 1990'lı yılların başlarında \%25-30'lara yükselmiştir. Günümüzdeki veriler bu oranı \%50-60 olarak vermektedir ${ }^{8}$. Türkiye'de HIV/AIDS olgularının cinsiyete göre dağılımına bakıldığında \%70'inin erkek, \%30'unun kadın olduğu gözlenmektedir. Olgular daha çok erkekler arasında ve 25-49 yaş grubunda görülmektedir. Çalışmamızdaki olguların \%60.7'sini erkek, \%39.3'ünü kadın olgular oluşturmaktadır. Verilen oranlara yakın olmakla birlikte, çalışmamızda kadın cinsiyetin biraz fazla oranda saptandığı görülmektedir. Ancak olguların yaklaşık yarısının yabancı uyruklu olgular oldu- 
ğu göz önüne alındığında T.C. vatandaşı olgular arasında \%80'ini (12/5) erkek, \%20'sini (3/15) kadın olgular oluşturmaktadır. Bu da Türkiye verileriyle uyumludur. Yabancı olgular arasındaki kadın olguların [\%61.5 (8/13)] sayıca fazla olduğu bunun da genel ortalamayı yükselttiği tespit edilmiştir. 2017 yılı Dünya Sağlık Örgütü (DSÖ)/UNAIDS verilerine göre; 19.6 milyon kişi Doğu ve Güney Afrika'da, 6.1 milyon kişi Batı ve Orta Afrika'da, 220.000 kişi Orta Doğu ve Kuzey Afrika'da, 5.2 milyon kişi Asya ve Pasifikler'de, 1.8 milyon kişi Latin Amerika'da, 310.000 kişi Karayipler'de, 1.4 milyon kişi Doğu Avrupa ve Orta Asya'da, 2.2 milyon kişi Batı-Orta Avrupa ve Kuzey Amerika'da yaşamaktadır. Sahraaltı Afrika'da HIV prevalansı \%4.8 olup, tüm bölgeler içinde en yüksek orandır. Ayrıca, kadın oranı da toplam HIV ile yaşayanların yarısından fazlasını oluşturmaktadır ${ }^{10}$. Bizim olgularımızdan, yabancı uyruklu olgular arasındaki kadın olguların beşinin Afrika uyruklu olduğu göz önüne alındığında güncel verilerle uyumlu olduğu söylenebilir.

Türkiye'de yapılan ilk HIV-1 alt tiplendirme çalışmasında ${ }^{11}$ alt tip B baskın (\%70.4) olarak bulunurken, son yıllarda yapılan araştırmalarda ${ }^{1,12-15}$ alt tip B ile birlikte CRF'lerde artan oranda görülmektedir. 2000-2007 yılları arasında 109 ülkeden 65.913 örneğin değerlendirildiği dünya çapındaki HIV-1 moleküler epidemiyolojik çalışmasına göre, CRF oranlarında artış, URF'de ise azalma saptanmaktadır ${ }^{3}$.

Çalışmamızda izole edilen 28 HIV-1 izolatının \%39.3'ünün alt tip B olduğu, ardından rekombinant izolatlar (CRF02_AG ve CRF01_AE) ve alt tip A'nın ikinci sıklıkta en yaygın HIV-1 tipi olduğu görülmektedir (Tablo II). Çalışmamızı oluşturan olgu sayımız düşük olmakla birlikte olgularımızın 15 (\%53.6)'ini T.C. vatandaşı, 13 (\%46.4)'ünü ise yabancı uyruklu olgular oluşturmaktadır. Genel dağılıma bakıldığında verilerimiz literatür bilgisi ile uyumlu görünmektedir. Alt tip B'nin daha çok T.C. vatandaşlarında saptandığı [10/15 (\%66.7)], yabancı uyruklu olgularda ise alt tip A'nın daha baskın [4/13 (\%30.8)] olduğu anlaşılmaktadır. Türkiye'ye özellikle Ortadoğu ve Balkan ülkelerinden yılda yaklaşık 300.000 göçmen gelmektedir. Ayrıca, Afrika'dan gelen yabancı öğrenci sayısı da azımsanmayacak düzeydedir. Türkiye $C$ ve $\mathrm{F}$ alt tiplerinin baskın olduğu kuzey komşuları için seks turizmi açısından çekici bir ülkedir ${ }^{11}$. Son yıllarda Suriye'den gelen mülteci sayısında da ciddi oranda bir artış olmuştur. Çalışmamızdaki alt tipler arasındaki heterojenlik, coğrafi konumu nedeniyle ülkemizdeki demografik değişikliklerle ilişkili olabilir.

HIV salgınının başlarında, otopsi çalışmaları, fırsatçı enfeksiyonların ve diğer hastalıkların çeşitliliğini ve sıklığını belirlemede önemli bir rol oynamıştır ${ }^{16}$. Özellikle Afrika'da HIV ile yüksek oranda devam eden ölüm oranlarına rağmen, ölüm nedenleri hakkında sınırı bilgi bulunmaktadır. Yaşam boyu tanı testine sınırlı erişimi olan bölgelerde, ölüm nedenlerini belirlemek için otopsi önem arz etmektedir ${ }^{17}$. Bu nedenle otopsi ölüm nedenlerini belirlemede hala altın standart yöntem olarak kalmaya devam etmektedir. Türkiye'de 2014-2018 yılları arasında bildirimi yapılan 12.992 HIV pozitif kişi ve 591 AIDS olgusu arasından 109 ölüm bildirilmiştir ${ }^{7}$. Ancak, ülkemizde sağlık kayıt sistemlerinin özellikle cinsel yolla bulaşan hastalıklar konusunda yeterli çalışmaması ve hastalığın uzun süren asemptomatik döneminin olması nedeniyle gerçek rakamların bunun çok üstünde olduğu tahmin edilmektedir. 
Özellikle Afrika bölgesinde HIV ile enfekte olmuş olgular üzerinde yapılan otopsi çaış̧malarında fırsatçı enfeksiyonların ölüm oranını arttırdığı tespit edilmiştir ${ }^{18}$. Fırsatçı enfeksiyonlar HIV/AIDS hastalarında önemli mortalite ve morbidite nedenlerindendir. HIV enfekte bireylerde sık görülebilen ko-enfeksiyonlar da, HIV enfeksiyonunun doğal seyrini etkileyebilmektedir. Hastalığın yayılması ve sıklığı coğrafi bölgeler arasında farklılıklar gösterdiği gibi saptanan fırsatçı enfeksiyonlar da bölgelere göre daha sık ve özgül olabilmektedir. Amerika kıtasında Latin kökenli HIV ile enfekte bireylerde en sık saptanan fırsatçı hastalıklar Pneumocystis jirovecii pnömonisi (PCP), tükenme sendromu ve özefageal kandidiyazken ${ }^{19}$; Çin'de yapılan bir çalışmada ise en sık karşılaşılan fırsatçı enfeksiyonların oral kandidiyaz, PCP ve tüberküloz olduğu bildirilmiştir ${ }^{20}$. Ülkemizden bildirilen çeşitli çalışmalarda ise en sık fırsatçı hastalıkların oral kandidiyaz, herpes zoster ve tüberküloz olduğu tespit edilmiştir ${ }^{21-23}$. Dünya çapında en sık görülen fırsatçı enfeksiyon hastalığı olan tüberkülozun, HIV enfeksiyonlu her üç hastadan birinin ölümünden sorumlu olduğu söylenmektedir ${ }^{24}$. Yapılan çalışmalarda HIV enfeksiyonu olanlarda tüberküloz gelişme riskinin 21-34 kat artmış olduğu tespit edilmiştir ${ }^{25}$. Otopsideki makroskobik bulgular, histopatolojik inceleme ve postmortem mikrobiyolojik inceleme sonuçları birlikte değerlendirildiğinde, çalışmamızdaki 28 olgunun 20'si (\%71.4) AIDS hastalığı ve buna bağlı gelişen komplikasyonlar sebebiyle kaybedilmiştir. Dört olguda çeşitli dokularda tüberküloz kültür ve PCR pozitifliği, iki olguda Toxoplasma enfeksiyonu (miyokardit ve meningoensefalit), bir olguda akciğer dokusunda PCP, bir olguda kan ve dalak kültürlerinde Cryptococcus neoformans üremesi, bir olguda kan, beyin omurilik sıvısı, akciğer, dalak dokusu ve apse kültürlerinde Streptococcus pyogenes üremesi, üç olguda HBV pozitifliği ve iki olguda da HCV pozitifliği saptanmıştır. Olgularımızda da izlendiği üzere fırsatçı enfeksiyonlar HIV enfeksiyonunun doğal seyrini etkileyerek, progresyonunu hızlandırmaktadır. Bu da literatürdeki sonuçları destekler niteliktedir.

Çalışma grubunda yer alan örneklerden ikisi PI bölgesi direnç mutasyonu saptanmasında, üç örnekte de RT bölgesi direnç mutasyonu saptanmasında başarısız olmuştur. Bu sayı az olmakla birlikte olgulardan postmortem numune alımında dikkat edilmesi gereken faktörler olduğuna dikkat çekmek istiyoruz. Postmortem mikrobiyolojinin başarısı, ölüm sonrası örnekleme protokolünün ve stratejisinin yeterliliğine bağlıdır ${ }^{26}$. Öncelikle otopsinin tercihen ölümden sonraki ilk 24 saat içerisinde yapılması önerilmektedir. En kısa zamanda da mikrobiyolojik numuneler alınmalıdır. Özellikle kan örneklerinin otopsi başlangıcında alınması gerektiği vurgulanmaktadır ${ }^{27}$. Genel prensip olarak da alınan numuneler oda sıcaklığında en az iki saat içerisinde, uygun taşıma ve saklama ortamlarında depolandığında ise 2 ila $8^{\circ} \mathrm{C}$ arasında 48 saat içerisinde laboratuvara ulaştırılmalıdır ${ }^{28}$. Serolojik ve moleküler incelemeler için postmortem alınacak olan kan örneklerinin yeterli miktarda alınamaması, uygun kalitede olmaması, uygun zaman aralığında toplanamamış olması moleküler incelemelerin kısıtlılıkları olarak karşımıza çıkmaktadır ${ }^{29,30}$.

Antiretroviral ilaçların tek başına kullanımı, kullanılan ilaca dirençli HIV mutantlarını ortaya çıkarmaktadır. Bu yüzden günümüzde kabul gören tedavi şekli genellikle anti- 
retroviral ilaçların uygun kombinasyonlar oluşturmak üzere bir arada kullanıldığı tedavi rejimi olan HAART (Highly Active Antiretroviral Therapy-Yüksek Düzeyde Aktif Antiretroviral Tedavi)'dır. Günümüzde, ART terimi HAART yerine kullanılmaktadır. İlaç kullanımının yüksek olduğu Batı ülkelerinde direnç oranları Belçika'da \%10.1, Fransa'da \%13.3, İsviçre'de \%15.1, İtalya'da \%18.3 düzeylerine ulaşmıştır ${ }^{28}$. Ülkemize yakın veya komşu konumdaki Gürcistan, Yunanistan, Romanya, Kıbrıs, İsrail ve Rusya'da saptanan primer direnç oranları sırasıyla \%8.3, \%1, \%6, \%5.4, \%10.1 ve \%7.3 olarak bildirilmektedir ${ }^{31}$. Çalışmamızda saptanan primer ilaç direnci oranları komşu ülkeler ve Batı Avrupa ülkelerinde saptanan oranlardan yüksek bulunmuştur. Bunun nedeni; olgu sayısı ve dağılımının ülkemizin tamamının temsili için az olmasıyla birlikte, olguların yaklaşık yarısını yabancı uyruklu olguların oluşturmasından ve AIDS hastalığı ve buna bağlı gelişen komplikasyonlar sebebiyle kaybedilen olgular olmasından kaynaklanıyor olabileceğini düşündürmektedir. Olguların ölüm öncesi ilaç kullanımı öykülerine ulaşılamamıştır.

Filogenetik analiz HIV-1 alt tiplerinin belirlenmesinde altın standart olarak kabul edilmektedir. Filogenetik analizlerde Neighbor-joining tekniği seçilmelidir. Adli tıp HIV sekanslarının kanıt olabilmesi için filogenetik analiz vazgeçilmezdir. Filogenetik analiz, ilk olarak 1992 yılında İsveç'teki bir hukuk mahkemesinde davalının ve şikayetçinin benzer HIV türlerini paylaşıp paylaşmadığını belirlemek için bilimsel kanıt olarak kullanılmıştır ${ }^{32}$. HIV pozitif bir kişi adli kanıt kullanılmadan Stockholm bölge mahkemesinde HIV'ın tecavüz ile kasıtlı bulaşmasından mahkum olmuştur. Ancak filogenetik analizin iki birey arasındaki bulaşını araştırmak için güvenilirliği ele alınmalıdır. Filogenetik analiz en çok belirli bireylerden ziyade genel popülasyonlar hakkındaki bilimsel araştırmalar bağlamında kullanılır. Araştırma ortamında filogenetik analiz, belirli bir yaklaşıklık ve hata derecesini tolere edebilir. HIV adli analizi için filogenetik ağaç oluşturulurken ağacın mümkün olduğu kadar tarafsız olması ve iyi seçilmiş kontrollerin kullanılması gerekir. Bununla birlikte, bulguların yorumlanmasında da özellikle dikkatli olunması gerekir. Adli olgularda HIV sekanslarının saptanması ve filogenetik analizi şüphelinin suçlu ya da masum olduğunun kanıtlanmasında diğer kanıtlarla birlikte değerlendirilmeli ve asla bir soruşturmanın merkezi noktası olmamalıdır ${ }^{32,33}$. HIV ile ilgili moleküler epidemiyolojik çalışmalar, o ülke içinde HIV alt tip paternlerinin ve yayılma yollarının izlenmesinde önemli olabilmektedir. Çalışmamızın sonuçları; olgu sayımızın az olmasıyla birlikte, ülkemizde B alt tipinin hala baskın olmasına rağmen, B olmayan alt tiplerin de bulunduğunu ve son yıllarda CRF oranında artış olduğunu bildiren diğer çalışma verileri ile paralellik göstermektedir. Çalışmamızda saptadığımız rekombinant suşlar; CRF02_AG Batı Afrika, Orta Afrika, Orta Doğu/ Kuzey Afrika kaynaklı; CRF01_AE Güney Doğu Asya, Doğu Asya ve Orta Afrika kaynaklı olmuştur $^{2}$. Ayrıca alt tip A, C ve F gibi diğer alt tip B dışı enfeksiyonların da ülkemizde dolaşımda bulunduğunu görmekteyiz. Bildiğimiz kadarıyla, çalışmamız ülkemizden bildirilen postmortem olgularla yapılan ilk HIV çalışmasıdır. HIV'ın ülkemize hangi yollardan girdiğinin ve nasıl yayıldığının anlaşııması için daha fazla moleküler epidemiyolojik çaıışmalara gereksinim bulunmaktadır. Sonuç olarak; T.C. Halk Sağlığı Genel Müdürlüğü Bulaşıcı Hastalıklar Daire Başkanlığının HIV ile ilgili istatistiklerinde yıllar içinde kümülatif 
HIV ve AIDS olgu sayıları, ölüm sayıları bunlara ilaveten yaş, cinsiyet, bulaş yolu gibi kimi demografik veriler bulunmaktadır. Ancak, AIDS olgularında ölüm nedeni olan fırsatçı enfeksiyonlar ve/veya patolojiler açık değildir. Makalemiz bu açıdan bu duruma bir pencere açmaktadır. Ayrıca; postmortem HIV sekanslarının bir veri tabanında toplanması fırsatı oluşmuş görünmektedir ve bu veri tabanı genişledikçe adli açıdan kullanılabilirliği ortaya çıkabilir. Bu nedenle HIV alt tip ve mutasyon bilgileri kullanışı olabilir. Öte yandan, bulgularımız alt tip ve mutasyon bilgisi dolaşımdaki HIV suşları hakkında fikir verirken aynı zamanda meydana gelen olayın niteliği/karakteri hakkında da fikir vermektedir. Bulgularımız, Adli Tıp Kurumunun bulaşıcı enfeksiyonlar yönünden bir çalışma perspektifi oluşturması gerektiğini gösterebilir. Biz bu perspektife HIV ile katkı yapmaya çalıştık

\section{ÇIKAR ÇATIŞMASI}

Yazarlar bu makale ile ilgili herhangi bir çıkar çatışması bildirmemişlerdir.

\section{KAYNAKLAR}

1. Sayan M, Kumbasar Karaosmanoğlu HK, Mete B, Gündüz A, Aydın Ö, Yemişen M, et al. Molecular epidemiological analysis of HIV-1 pol gene sequences isolated in Istanbul, Turkey. Mikrobiyol Bul 2013;47(1):87-97.

2. Hemelaar J. Implications of HIV diversity for the HIV-1 pandemic. J Infect 2013;66(5):391-400.

3. Hemelaar J, Gouws E, Ghys PD, Osmanov S. Global trends in molecular epidemiology of HIV-1 during 20002007. AIDS 2011;25(5):679-89.

4. Robertson DL, Anderson JP, Bradac JA, Carr JK, Foley B, Funkhouser RK, et al. HIV-1 nomenclature proposal. Science 2000;288(5463):55-6.

5. Del Rio C, Curran JW. Epidemiology and prevention of acquired immunodeficiency syndrome and human immunodeficiency virus infection, pp: 1340-69. In: Mandell GL, Douglas RG, Bennett JE (eds), Principles and Practice of Infectious Diseases. 2000. John Wiley, New York.

6. Prevention gap report Geneva: UNAIDS; 2017. http://www.unaids.org/en/resources/fact-sheet.

7. https://hsgm.saglik.gov.tr/tr/bulasici-hastaliklar/862-hiv-aids/1135-hiv-aids-istatislik.html

8. Tümer A, Ünal S. HIV/AIDS epidemiyolojisi ve korunma, pp: 1-18. In: Ünal S (ed). Güncel Bilgiler Işığında HIV/AIDS. 2016, 4. Baskı. Bilimsel Tıp Yayınevi, Ankara.

9. Liu TF, Shafer RW. Web resources for HIV type 1 genotypic-resistance test interpretation. Clin Infect Dis 2006;42(11):1608-18.

10. www.unaids.org UNAIDS Data 2018. Regional HIV and AIDS statistics and features 2017.

11. Yilmaz G, Midilli K, Türkoğlu S, Bayraktaroğlu Z, Kuşkucu AM, Ozkan E, et al. Genetic subtypes of human immunodeficiency virus type 1 (HIV-1) in Istanbul, Turkey. Int J Infect Dis 2006;10(4):286-90.

12. Sayan M, Willke A, Ozguneş N, Sargın F. HIV-1 subtypes and primary antiretroviral resistance mutations in antiretroviral therapy naive HIV-1 infected individuals in Turkey. Jpn J Infect Dis 2013;66(4):306-11.

13. Alpsar D, Agacfidan A, Lübke N, Verheyen J, Eraksoy H, Cagatay A, et al. Molecular epidemiology of HIV in a cohort of men having sex with men from Istanbul. Med Microbiol Immunol 2013;02(3):251-5.

14. Uluer Biçeroğlu S, Altuğlu I, Nazli Zeka A, Gökengin D, Yazan Sertöz R. HIV-1 subtype distribution determined by phylogenetic analysis of pol gene sequences and automated subtyping tools among HIV-1 isolates from the Aegian Region of Turkey. Mikrobiyol Bul 2014;48(3):420-8.

15. Sayan M, Sargin F, Inan D, Sevgi DY, Celikbas AK, Yasar K, et al. HIV-1 transmitted drug resistance mutations in newly diagnosed antiretroviral-naive patients in Turkey. AIDS Res Hum Retroviruses 2016;32(1):26-31.

16. Lucas S. Causes of death in the HAART era. Curr Opin Infect Dis 2012;25(1):36-41. 
17. Cox JA, Lukande RL, Nelson AM, Mayanja-Kizza H, Colebunders R, Van Marck E, et al. An autopsy study describing causes of death and comparing clinico-pathological findings among hospitalized patients in Kampala, Uganda. PLoS One 2012;7(3):e33685.

18. Cox JA, Lukande RL, Lucas S, Nelson AM, Van Marck E, et al. Autopsy causes of death in HIV-positive individuals in sub-Saharan Africa and correlation with clinical diagnoses. AIDS Reviews 2010;12:183-94.

19. Wohl AR, Lu S, Turner J, Kovacs A, Witt M, Squires K, et al. Risk of opportunistic infection in the HAART era among HIV-infected Latinos born in the United States compared to Latinos born in Mexico and Central America. AIDS Patient Care STDS 2003;17(6):267-75.

20. Wang XC, Huang XJ, Zhang T, Liang LC, Jiao YM, et al. The characteristics of opportunistic infections in 181 HIV/AIDS patients in China. Zhonghua Nei Ke Za Zhi 2007;46(5):379-82.

21. Karaosmanoglu HK, Aydin OA, Nazlican O. Profile of HIV/AIDS patients in a tertiary hospital in Istanbul, Turkey. HIV Clin Trials 2011;12(2):104-8.

22. Kaptan F, Ormen B, Turker N, El S, Ural S, Vardar I, et al. İnsan immun yetmezlik virüsü ile enfekte 128 olgunun retrospektif olarak değerlendirilmesi.Türkiye Klinikleri Tıp Bilimleri Dergisi 2011;31(3):525-33.

23. Yardımcı AC, Fincancı M. HIV infeksiyonlu hastalarda fırsatçı hastalıkların viral yük ve CD4+ T hücre sayılarıyla ilişkisi. Klimik Dergisi 2015;28(1):28-34.

24. Raviglione MC, Snider DE Jr, Kochi A. Global epidemiology of tuberculosis. Morbidity and mortality of a worldwide epidemic. JAMA 1995;273(3):220-6.

25. Guidelines for Intensified Tuberculosis Case-finding and Isoniazid Preventive Therapy for People Living with HIV in Resource-constrained Settings [internet]. Geneva: World Health Organization [erişim 30.12.2018]. http://apps.who.int/iris/bitstream/handle/10665/44472/9789241500708_eng.pdf

26. Caplan MJ, Koontz FT. Post-mortem microbiology. In: McCurdy BW (ed). 2001, Cumitech 35. ASM Press, Washington DC.

27. Fernández-Rodríguez A, Cohen MC, Lucena J, Van de Voorde W, Angelini A, Ziyade N, et al. How to optimise the yield of forensic and clinical post-mortem microbiology with an adequate sampling: a proposal for standardisation. Eur J Clin Microbiol Infect Dis 2015;34(5):1045-57.

28. Baron EJ, Miller JM, Weinstein MP, Richter SS, Gillian PH, Thomson RB Jr, et al. A guide to utilization of the microbiology laboratory for diagnosis of infectious diseases: 2013 recommendations by the Infectious Disease Society of American (IDSA) and the American Society for Microbiology (ASM). Clin Infect Dis 2013;57:e22-e121.

29. Kitchen AD, Newham JA. Qualification of serological infectious disease assays for the screening of samples from deceased tissue donors. Cell Tissue Bank 2011;12(2):117-24.

30. Kitchen AD, Gillan HL. The serological screening of deceased tissue donors within the English Blood Service for infectious agents- a review of current outcomes and a more effective strategy for the future. Vox Sang 2010;98 (3 Pt 1):e193-200.

31. https://hivdb.stanford.edu/page/surveillance-map/

32. Bernard EJ, Azad Y, Vandamme AM, Weait M, Geretti AM. HIV Forensics: pitfalls and acceptable standards in the use of phylogenetic analysis as evidence in criminal investigations of HIV transmission. HIV Med 2007;8(6):382-7.

33. Learn $\mathrm{GH}$, Mullins Jl. The microbial forensic use of HIV sequences. pp: 22-37. In: Leitner T, McCutchan F, Foley B, et al. (eds). HIV Sequence Compendium. Los Alamos, NM: Theoretical Biology and Biophysics Group, Los The accuracy of laser scanning technology on the determination of bloodstain origin. 